\title{
Sosialisasi dan Instalasi Panel Surya Sebagai Energi Terbarukan Menuju Kesadaran Lingkungan Indonesia Bebas Emisi
}

\author{
Rr. Mekar Ageng Kinasti ${ }^{1}$; Desi Puti ${ }^{2}$; Endah Lestari ${ }^{3}$; Muhammad Sofyan ${ }^{4}$ \\ Irma Wirantina $\mathbf{K}^{5}$; Ranti Hidayawanti ${ }^{6}$; Iriansyah BM. Sangadji ${ }^{7}$

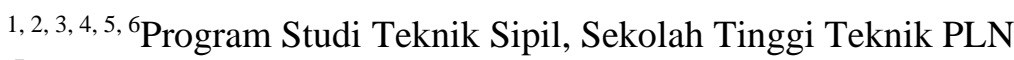 \\ ${ }^{7}$ Program Studi Teknik Informatika, Sekolah Tinggi Teknik PLN \\ ${ }^{1}$ mekar.ageng@sttpln.ac.id
}

\begin{abstract}
ABSTRAK
Perubahan iklim yang terjadi saat ini sebagai dampak ketidakeimbangan tingkat CO2 di atmosfer sebagai emisi dari penggunaan energi berbahan baku karbon serta prediksi kebutuhan akan energi dimasa depan, serta meningkatnya biaya pemenuhan kebutuhan listrik berbahan fosil terkait dua alasan yang melatarbelakangi Program Kemitraan Masyarakat (PKM) ini dilakukan. PKM ini dilakukan dengan memberikan sosialisasi kepada masyarakat tentang pemanfaatan sel surya sebagai sumber energi alternatif yang sangat dekat dengan kehidupan kita setiap harinya, serta latar belakang perlunya kita mempergunakan energi alternatif tersebut di harapkan mampu membuka wawasan sekaligus memberikan motivasi kepada pihak Mitra untuk melakukan pengembangan pemanfaatannya sebagai bentuk kepedulian kita terhadap masa depan bumi yang akan datang. Dengan sampainya informasi pemutakhiran serta penerapannya kepada masyarakat, hal tersebut dapat memotivasi Mitra untuk mengembangkan pemanfaatan panel surya di SMPN 462 dengan lebih baik sehingga dapat menjadi sekolah yang mandiri dalam memenuhi kebutuhan energi listrik di sekolah tersebut. Optimalisasi tujuan PKM memerlukan keseriusan serta kepedulian dari berbagai lapisan elemen masyarakat seperti tim pelaksana, institusi tim pelaksana, serta pihak Mitra guna meningkatkan kesejahteraan kehidupan bermasyarakat serta turut menjaga kelestarian lingkungan hidup menuju Indonesia Bebas Emisi.
\end{abstract}

Kata Kunci: panel surya, sel surya, energi terbarukan, lingkungan hidup

\begin{abstract}
The current climate change as a result of the imbalance of $\mathrm{CO} 2$ levels in the atmosphere as emissions from carbon-based energy use as well as predictions of future energy needs, as well as increasing costs of meeting fossil fuel-related electricity needs are two reasons behind this Community Partnership Program (PKM). This PKM is conducted by giving socialization to the public about the use of solar cells as an alternative energy source that is very close to our lives every day, and the background of our need to use alternative energy is expected to open insights and provide motivation to Partners to develop their use as a form of our concern for the future of the upcoming earth. With the arrival of information on updates and their application to the community, this can motivate Partners to develop better use of solar panels at SMPN 462, so that they can become independent schools in meeting the electricity needs of the school. Optimizing PKM goals requires seriousness and concern from various layers of community elements such as the implementation team, implementing team, and partners to improve community welfare and contribute to environmental preservation towards an Emission-Free Indonesia.
\end{abstract}

Keywords: solar panels, solar cells, alternative energy, renewable energy, environment 


\section{PENDAHULUAN}

\subsection{Analisis Situasi}

Perubahan iklim yang terjadi pada saat ini merupakan salah satu dampak dari ketidakeimbangan emisi di udara. $\mathrm{CO} 2$ telah mengalami peningkatan konsentrasi di udara. Selama bertahun-tahun kita telah terus menerus melepaskan karbondioksida ke atmosfir dengan menggunakan bahan bakar yang berasal dari fosil seperti batubara, gas bumi dan minyak bumi. Hal ini telah menyebabkan meningkatnya selimut alami dunia, yang menuju kearah meningkatnya suhu iklim dunia, dan perubahan iklim yang tidak dapat diprediksi juga mematikan Fenomena ini terjadi setelah rentang yang sangat panjang, ditandai dengan perubahan pola cuaca dalam data statistiknya sepanjang periode waktu.

Listrik, tidak dapat dipungkiri telah beralih menjadi kebutuhan primer manusia. Seiring dengan meningkatnya permintaan akan listrik, tarif dasar listrikpun akan mengalami kenaikan. Kenaikan tarif dasar listrik berlanjut di tahun 2014 sampai dengan tahun 2017. Kenaikan tarif dasar listrik ini merupakan langkah yang harus diambil ketika PLN mengalami kerugian, salah satu penyebab kerugian PLN tersebut adalah mahalnya biaya operasional untuk pembelian bahan bakar pembangkit. Hal ini menjadi permasalahan yang sulit yang harus dicari jalan tengahnya agar pasokan energi dapat mengimbangi banyaknya permintaan akan tetapi rendah emisi, sehingga perubahan iklim dapat di tekan.

Penggunaan energi terbarukan merupakan alternative untuk mengurangi permintaan energi ke PLN dan pengoptimalan potensi alam. Dimasa yang akan datang, menusia akan beranjak menuju penggunaan energi alternatif yang lebih bersih dan bebas emisi karbon. Hal ini akan dapat diwujudkan bila terjadi perubahan pola konsumsi energi pada sektor-sektor pengkonsumsi energi besar seperti built environment, industri, transportasi, serta power generation, dan generasi muda penerus bangsa mengerti dan memahami betul kondisi yang terjadi saat ini sehingga peduli akan kelangsungan kelestarian lingkungannya. Dekarbonisasi suatu Negara akan bergantung pada beberapa faktor, salah satunya geografi negara tersebut. Negara dengan potensi energi baru dan terbarukan yang besar seperti angina, air, dan matahari akan lebih cepat melakukan dekarbonisasi dibandingkan dengan negara yang tidak memiliki sumber daya tersebut.

Sebagai upaya untuk memenuhi kebutuhan tenaga listrik tersebut sekaligus penanggulangan kondisi krisis penyediaan tenaga listrik di beberapa daerah, maka dapat memanfaatkan Potensi alam untuk dijadikan energi listrik. Salah satu Potensi alam sebagai sumber energi listrik adalah energi tenaga matahari. Sel surya merupakan teknologi yang mengubah cahaya matahari menjadi energi listrik (Hasyim dkk). Matahari merupakan sumber energi utama bagi sebagian besar proses-proses yang terjadi dipermukaan bumi. Radiasi matahari yang diterima permukaan bumi merupakan masukan fundamental untuk banyak aspek terutama merupakan parameter penting dalam aplikasi solar sel sebagi pembangkit listrik. sel matahari merupakan piranti yang dapat meng-konversi cahaya matahari menjadi energi listrik. Energi matahari dapat menghasilkan daya hingga 156.486 MW, jumlah yang lebih besar jika dibandingkan dengan sum-ber energi terbarukan yang lainnya. Indonesia merupakan negara yang terletak da-lam jalur khatulistiwa yang sepanjang tahun mendapatkan cahaya matahari yang berlimpah dengan intensitas radiasi mata-hari rata-rata sekitar $4.8 \mathrm{kWh} / \mathrm{m}^{2}$ per hari di seluruh wilayah Indonesia (Rusman,2015).

Energi baru dan terbarukan mempunyai peran yang sangat penting dalam memenuhi kebutuhan energi. Hal ini disebabkan penggunaan bahan bakar untuk pembangkit-pembangkit listrik konvensional dalam jangka waktu yang panjang akan menguras sumber minyak bumi, gas dan batu bara yang semakin menipis dan juga dapat mengakibatkan pencemaran lingkungan. Selain itu, di 
Indonesia yang merupakan daerah tropis mempunyai potensi energi matahari sangat besar (Ima dkk, 2013).

\subsection{Tujuan Kegiatan}

Tujuan kegiatan PKM Sosialisasi Pemanfaatan Sel Surya Sebagai Sumber Energi Terbarukan Dan Instalasi Panel Surya ini adalah:

a. Bagi Mitra:

1) Munculnya Sikap Peduli Lingkungan Menuju Indonesia Bebas Emisi bagi siswa dan seluruh elemen di SMP Negeri 264 Jakarta Barat

2) Meningkatkan pemahaman pada siswa dan seluruh civitas SMP Negeri 264 Jakarta Barat tentang sumber energi listrik terbarukan yang ramah lingkungan dan efisien.

3) Jika Mitra melakukan pengembangan dalam skala yang lebih besar maka, dampak ekonomi akan dapat dirasakan dengan lebih karena dapat menekan pembiayaan kebutuhan listrik.

b. Bagi STT PLN:

Sosialisasi Sosialisasi Pemanfaatan Sel Surya Sebagai Sumber Energi Terbarukan Dan Instalasi Panel Surya ini dapat meningkatkan citra STT PLN di masyarakat umum sebagai Sekolah Tinggi milik Perusahaan Listrik Negara yang peduli terhadap kelestarian lingkungan dengan meningkatkan kualitas kehidupan masyarakat melalui serta menjadikan listrik sebagai pendorong kegiatan ekonomi dengan berwawasan lingkungan sehingga mampu menyelaraskan berbagai aspek seperti ekonomi, sosial dan lingkungan serta mencegah krisis energi di masa yang akan datang.

c. Bagi Tim PKM Jurusan Teknik Sipil STT PLN:

1) Keberhasilan dalam Sosialisasi Pemanfaatan Sel Surya Sebagai Sumber Energi Terbarukan Dan Instalasi Panel Surya ini dapat memberikan semangat dan motivasi bagi Tim guna mengembangkan Program Kemitraan Masyarakat dalam aspek yang lebih luas.

2) Tim dapat mengaplikasikan ilmu dan kemampuan yang dimilikinya sebagai bentuk pelayanan kepada masyarakat.

\subsection{Rancangan Solusi}

Dalam rangka menyelesaikan permasalahan yang muncul pada situasi saat ini, rancangan solusi yang dapat diberikan oleh TIM PKM Jurusan Sipil STT PLN adalah:

a. Memberikan sosialisasi bagi seluruh civitas SMP Negeri 264 Jakarta Barat untuk mengenali permasalahan lingkungan dan solusinya dengan mengembangkan teknologi rendah emisidalam menghadapi perubahan iklim yang terjadi.

b. Memberikan sosialisasi bagi seluruh civitas SMP Negeri 264 Jakarta Barat tentang pemanfaatan sumber daya alam yang keberadaannya melimpah disekitar kita yaitu mengkonversi cahaya matahari menjadi energi listrik.

c. Memberikan sosialisasi bagi seluruh civitas SMP Negeri 264 Jakarta Barat bahwa pengupayaan penggunaan energi terbarukan yang dilakukan saat ini dapat mencegah krisis energi dimasa yang akan datang.

d. Memberikan sosialisasi bagi seluruh civitas SMP Negeri 264 Jakarta Barat tantang manfaat lain penggunaan panel surya dalam bidang ekonomi. 
e. Memberikan arahan pada praktek pemasangan dan pemanfaatan Panel Surya di Lingkungan SMP Negeri 264 Jakarta Barat.

\section{METODE PELAKSANAAN}

\subsection{Pendidikan Masyarakat}

Kegiatan ini memilih menggunakan metode Pendidikan Masyarakat, hal ini mengingat di lingkungan ini belum memiliki informasi lebih tentang pemanfaatan Sel Surya melalui Panel Surya. Dengan memberikan Pendidikan Masyarakat khususnya dilingkungan sekolah dan peserta didik, diharapkan informasi ini akan mudah tersebar dan akhirnya membentuk budaya cinta lingkungan.

Sosialisasi Pemanfaatan Sel Surya Sebagai Sumber Energi Terbarukan Dan Instalasi Panel Surya ini dilakukan dalam dua sesi yang diikuti oleh 20 - 30 peserta. Sesi pertama atau hari pertama kegiatan merupakan sesi teori. Pada sesi ini sosialisasi dilakukan. Materi diberikan kepada seluruh peserta kegiatan. Materi yang diberikan antara lain berupa pengetahuan tentang isu lingkungan global, pengetahuan pemanfaatan energi terbarukan yang berasal dari Sel Surya, sesi pertama diakhiri dengan diskusi juga tanya jawab dengan peserta kegiatan.

Sesi kedua dilakukan pada hari kedua. Pada sesi kedua ini dilakukan praktek pemasangan dan pemanfaatan sel surya yang berasal dari matahari. Instalasi panel surya ini dilakukan oleh seluruh anggota tim dan Mitra.

\subsection{Permasalahan Mitra}

Mitra masyarakat yang akan bekerjasama dalam melaksanakan Program Kemitraan masyarakat Jurusan Teknik Sipil ini adalah SMP Negeri 264 yang berlokasi di Keluarah Rawa Buaya Jakarta Barat. SMP N 264 merupakan wadah akademik dalam mengelola generasi penerus bangsa secara intelektual yang sangat besar potensinya untuk merubah model penggunaan energi konvensional dan beralih menjadi energi terbarukan dimasa yang akan datang melalui sosialisasi yang akan diberikan.

Target peserta yang akan mengikuti acara ini adalah 20 (dua puluh) orang antara lain:

1. Seluruh civitas akademik SMP Negeri 264 yang berkenan hadir mengikuti acara sosialisasi pemanfaatan sel surya sebagai sumber energi alternatif.

\section{Pengurus dan Anggota OSIS SMP N 264}

Penggunaan energi listik di ruang lingkup wilayah mitra tentunya sangat diperlukan guna menunjang sarana pendidikan. Pemasangan Panel Surya dan Pemanfaatan Sel Surya Sebagai Sumber Energi Terbarukan di Lokasi Mitra diharapkan dapat membantu Mitra dalam menekan penggunaan energi listrik yang kemudian dapat dikembangkan pemanfaatannya di beberapa bagian yang termasuk ruang lingkup wilayah mitra yang kemudian akan dapat di rasakan manfaatnya dalam skala yang lebih besar.

\section{HASIL DAN PEMBAHASAN}

\subsection{Hasil}

Kegiatan sosialisasi pemanfaatan sel surya sebagai sumber energi terbarukan dan instalasi panel surya dalam rangka menumbuhkan sikap peduli lingkungan menuju indonesia bebas emisi telah dilaksanakan dan berlangsung dengan baik di SMP Negeri 264 Jakarta Barat. Hasil dari kegiatan sosialisasi pemanfaatan sel surya sebagai sumber energi terbarukan dan instalasi panel surya ini di fokusnya pada tujuan awal kegiatan PKM ini, antara lain sebagai berikut:

1. Melalui kegiatan sosialisasi ini kami tim kegiatan PKM telah membantu menyebarluaska dan sekaligus menerapkan hasil- hasil penelitian/ kajian kepada masyarakat sebagai Bagian 
dari upaya untuk memberdayakan danmeningkatkan kualitas hidup masyarakat dengan pemutakhiran teknologi yang ada.

2. Melalui kegiatan PKM ini merupakan bentuk kerjasama dan kemitraan dengan masyarakat sebagai perwujudan dari pengembangan kompetensi sosial di kalangan para dosen.

3. Panel surya telah dimanfaatkan sesuai dengan penggunaannya di SMP N 264 Jakarta Barat, tepatnya pada koridor depan ruang kelas sebanyak 4 titik serta dalam keadaan baik sampai hari ini.

4. Seluruh Civitas SMP N 264 menjadi lebih paham dan mengerti bagaimana sumber energi listrik terbarukan yang ramah lingkungan dan efisien, serta bagaimana mensiasati pemenuhan kebutuhan energi di tengah harga listrik yang terus naik.

\subsection{Pembahasan}

Sesuai dengan rencana target luaran, dengan dilaksanakannya kegiatan sosialisasi pemanfaatan sel surya sebagai sumber energi terbarukan dan instalasi panel surya kali ke dua ini diharapkan dapat membantu meningkatkan penerapan IPTEK di kalangan masyarakat umum, dimulai dari kalangan pendidik dan pelajar, khususnya pengurus OSIS, dengan harapan program ini akan dengan mudah tersosialisasikan dan akhirnya sampai pada khalayak umum diluar zona pendidikan.

Acara sosialisasi pemanfaatan sel surya sebagai sumber energi terbarukan dilakukan pada hari Senin, 21 Mei 2018 pada pukul 09.00 WIB sampai dengan selesai, sedangkan pemasangan panel surya telah dilakukan pada hari Jumat, 25 Mei 2018 dimulai dari pukul 09.00 sampai dengan selesai. Acara sosialisasi tersebut dihadiri tim PKM yang terdiri dari dosen Jurusan Teknik Sipil STT PLN Jakarta serta diikuti oleh 29 peserta yang terdiri dari Kepala Sekolah, Bapak/ Ibu guru, siswa-siswi pelajar, khususnya para pengurus OSIS di SMP N 264 Jakarta Barat.

Kegiatan PKM kali ini tentusaja belum mampu menyelesaikan seluruh permasalahan Mitra yaitu pemenuhan kebutuhan listrik yang tinggi selama pelaksanaan kegiatan belajar mengajar berlangsung, akan tetapi setidaknya melalui kegiatan PKM ini, Mitra menjadi lebih terbuka bahwa selain permasalahan finansial dalam pemenuhan kebutuhan listrik, ada permasalahan lain yang tidak kalah pentingnya yaitu kerusakan lingkungan hidup sebagai akibat dari meningkatnya permintaan listrik oleh masyarakat yang bersumber dari bahan bakar fosil. Permasalahan lingkungan yang telah mendunia ini tidaklah menjadi tanggung jawab pemerintah saja, melainkan menjadi tanggung jawab seluruh masyarakat di belahan dunia manapun. Dengan demikian dengan melakukan sosialisai pemanfaatan sel surya serta pemasangan panel surya sebagai sebagai sumber energi alternatif guna pemenuhan kebutuhan listrik, diharapkan menjadi salah satu metode yang efektif dalam rangka mewujudkan Indonesia bebas emisi dan menjaga kelestarian lingkungan hidup. 


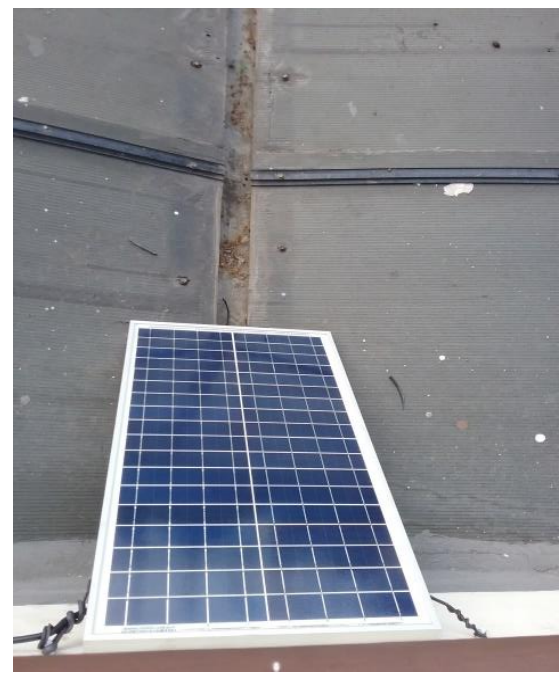

Gambar 1. Penempatan panel surya di atap kanopi Lantai dua SMP N 264 Jakarta Barat

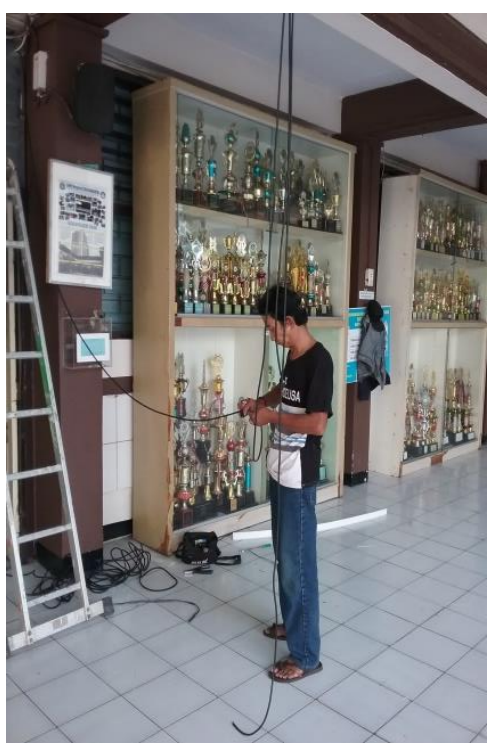

Gambar 3. Instalasi pemasangan kabel panel surya di SMPN 264 Jakarta Barat.

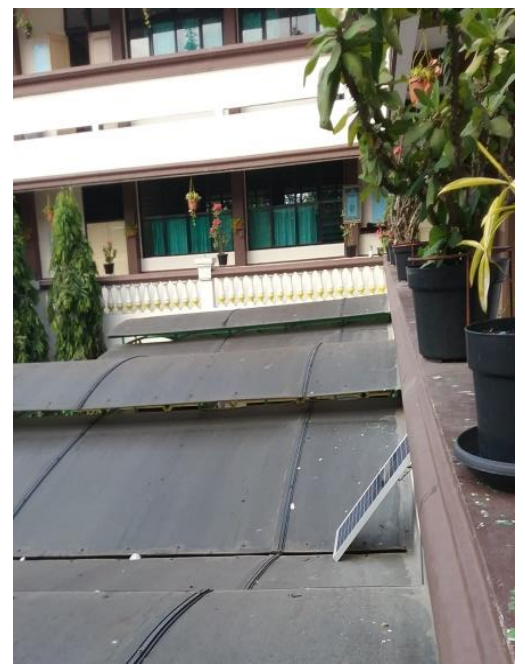

Gambar 2. Penempatan panel surya di atap kanopi lantai dua SMP N 264 Jakarta Barat (Tampak samping).

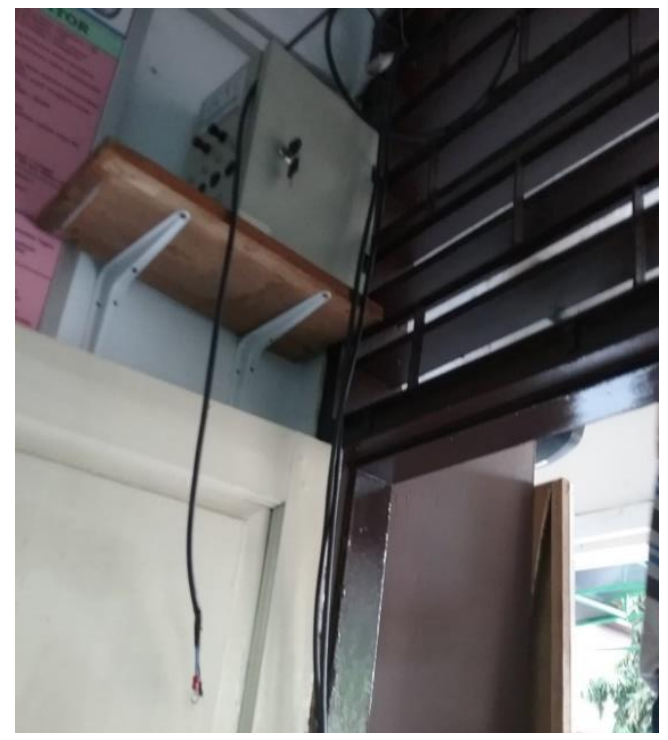

Gambar 4. Penempatan box kontrol panel suraya berapa pada ruang Kepala Sekolah SMP N 264 Jakarta Barat. 


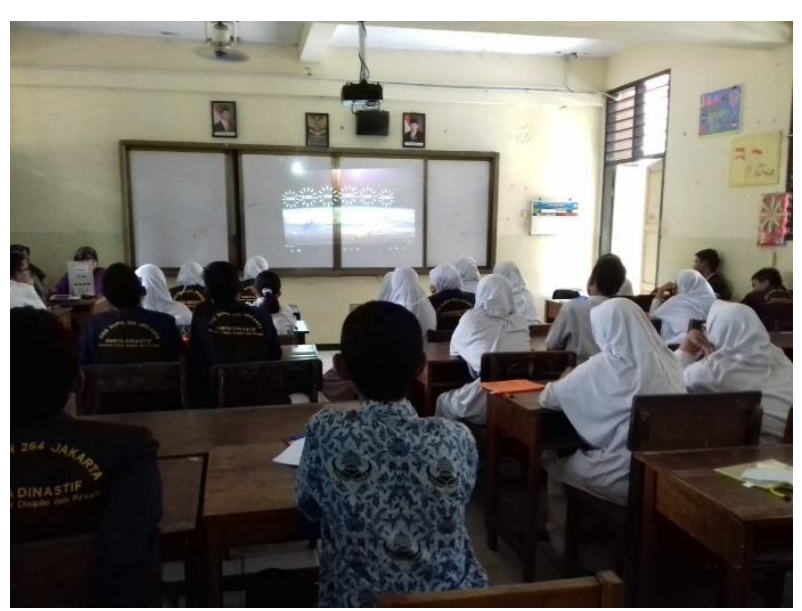

Gambar 5. Penayangan video animasi proses global warming sebagai akibat naiknya polutan akibat pemakaian bahan bakar fosil.

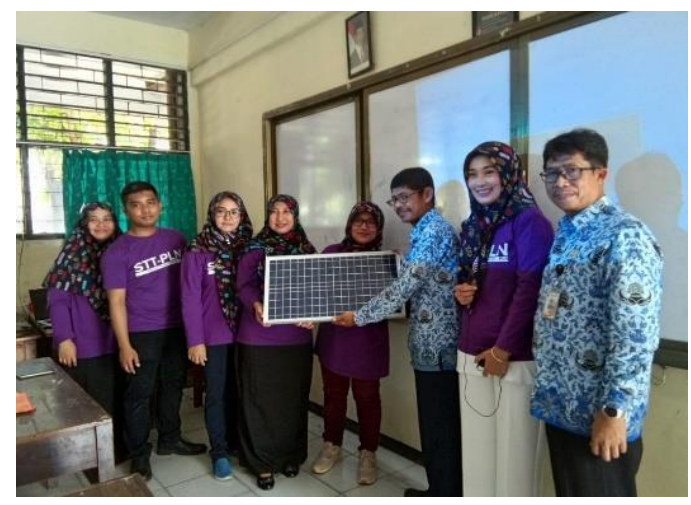

Gambar 6. Penyerahan panel surya secara simbolis di terima oleh perwakilan dari SMPN 264 Jakarta Barat.

\subsection{Kendala yang Dihadapi}

Pelaksanaan program kemitraan ini tidak luput dari kendala-kendala yang muncul di lapangan, beberapa kendala yang kami hadapi antara lain:

1. Kesesuaian waktu pelaksanaan yang sempat berubah beberapa kali, hal tersebut di karenakan tingkat kesibukan dari Tim PKM serta Mitra yang relatif tinggi dan bertepatan dengan bulan Ramadhan dan libur lebaran, serta kegiatan belajar siswa-siswi yang sangat padat.

2. Kendala lain adalah tingginya harga panel surya yang dipergunakan sebagai media pemanfaatan sel surya jika dibandingkan dengan jumlah dana kegiatan. Jadi meskipun pihak Mitra telah mendapatkan hasil serta manfaat dikarenakan berkurangnya pemenuhan kebutuhan akan lsitrik PLN, akan tetapi dirasakan kurang maksimal karena jumlah daya yang di hasilkan tidak begitu banyak.

\subsection{Evaluasi Kegiatan}

Hasil evaluasi yang didapatkan dari kegiatan Program Kemitraan Masyarakat di SMPN 264 merujuk pada latar belakang kegiatan, kondisi saat kegiatan berlangsung, tujuan kegiatan serta kendala yang muncul selama kegiatan berlangsung adalah:

1. Mitra terlihat sangat antusias menerima informasi tentang pemanfaatan sel surya melalui panel surya, hal tersebut nampak pada respon peserta dalam sesi tanya-jawab dan interaksi yang muncul selama sosialisai berlangsung dimulai dari tahap persiapan, pelaksanaan dan pemasangan panel surya yang berlangsung sampai sore hari masih diikuti oleh sebagian siswa hingga kepala sekolah.

2. Tingginya harga pemasangan awal panel surya yang menjadi kendala dapat terjawab dengan pelaksanaan PKM terhadap satu Mitra dilakukan lebih dari satu kali, sehingga dampak positif yang muncul sebagai akibat dari terpasangnya panel surya di sekolahan tersebut dapat lebih terasa. 


\section{KESIMPULAN DAN SARAN}

\subsection{Kesimpulan}

Kesimpulan yang dapat di ambil dari seluruh rangkaian acara Program Kemitraan Masyarakat dengan judul sosialisasi Pemanfaatan Sel Surya Sebagai Sumber Energi Terbarukan Dan Instalasi Panel Surya Dalam Rangka Menumbuhkan Sikap Peduli Lingkungan Menuju Indonesia Bebas Emisi, adalah :

1. Melalui program kegiatan kemitraan yang dilakukan dengan memberikan sosialisasi kepada masyarakat tentang pemanfaatan sel surya sebagai sumber energi alternatif yang sangat dekat dengan kehidupan kita setiap harinya, serta latar belakang perlunya kita mempergunakan energi alternatif tersebut di harapkan mampu membuka wawasan sekaligus memberikan motivasi kepada pihak Mitra untuk melakukan pengembangan pemanfaatannya sebagai bentuk kepedulian kita terhadap masa depan bumi dikemudian hari.

2. Dengan sampainya informasi pemutakhiran serta penerapannya kepada masyarakat, hal tersebut dapat memotivasi Mitra untuk mengembangkan pemanfaatan panel surya di SMPN 462 dengan lebih baik sehingga menjadi sekolah yang mandiri dalam memenuhi kebutuhan energi listrik di sekolah tersebut.

3. Optimalisasi tujuan PKM memerlukan keseriusan serta kepedulian dari berbagai lapisan elemen masyarakat seperti tim pelaksana, institusi tim pelaksana, serta pihak Mitra guna meningkatkan kesejahteraan kehidupan bermasyarakat serta turut menjaga kelestarian lingkungan hidup menuju Indonesia Bebas Emisi.

4. Berdasarkan evaluasi yang dilakukan terhadap kegiatan ini menunjukkan bahwa kegiatan ini masih dapat dilanjutkan kembali mengingat adanya permintaan dari pihak sekolah lain sebagai mitra selanjutnya. Serta skala sosialisasinya dapat lebih diperluas guna mendapatkan hasil yang lebih maksimal.

\subsection{Saran}

Berdasarkan kendala serta uraian kegiatan diatas, saran yang dapat kami berikan antara lain sebagai berikut:

1. Langkah yang dapat ditempuh guna mengatasi tingginya harga instalasi panel surya adalah dengan membangun kerjasama dengan pihak produsen panel surya dalam rangka menyukseskan kegiatan sosialisai pemanfaatan sumber energi alternatif ini, sehingga tim pelaksana PKM bisa mendapatkan harga beli dan instalasi panel surya yang lebih rendah dibandingkan harga yang sebelumnya.

2. Sebaiknya Mitra melakukan pengembangan dalam skala yang lebih besar secara mandiri agar dampak ekonomi dapat dirasakan dengan lebih karena dapat menekan pembiayaan kebutuhan listrik yang selama ini dibebankan.

3. Pemilihan lokasi PKM selanjutnya diharapkan benar-benarmempertimbangkan dari sisi kebutuhan pihak Mitra, yaitu Mitra yang benar-benar membutuhkan bantuan tenaga Listrik atau pada daerah-daerah yang belum sepenuhnya di aliri oleh listrik. 


\section{UCAPAN TERIMA KASIH}

Penulis mengucapkan terima kasih kepada Instansi/perusahaan/lembaga yang telah memberi dukungan yang membantu pelaksanaan kegiatan pengabdian pada masyarakat, khususnya LPPM STT PLN dan SMPN 462 Jakarta Barat.

\section{DAFTAR PUSTAKA}

[1] Hasyim Asy'ari., 2014, Pemanfaatan Solar dengan PLN sebagai Sumber Energi Listrik Rumah Tinggal. Jurnal Emitor Volume 14.

[2] Heri, J., 2011, Jurnal Ilmiah, Pengujian Sistem Pembangkit Listrik Tenaga Surya Solar Cel Kapasitas 50wp.

[3] Ikhsan., 2013, Jurnal ilmiah Dosen pada Jurusan Fisika Fakultas Sains dan Teknologi UIN Alauddin Makassar, Peningkatan Suhu Modul Dan Daya Keluaran Panel Surya Dengan Menggunakan Reflektor.

[4] Ima Maysha., 2103. Pemanfaatan Tenaga Surya Menggunakan Rancangan panel Surya Berbasis Transistor 2N3055 dan Thermoelectric Cooler.

[5] Rusman.,2015. Pengaruh Variasi Beban Terhadap Efisiensi Solar Cell dengan Kapasitas 50 WP. Jurnal Turbo Vol. 4. No.2. 2015. 